\title{
Issues and Challenges in Teaching Multicultural Music amongst Primary Music Teachers in Malaysia
}

\author{
Wong Kwan Yie and Chiu Ming Ying \\ Department of Music, Cultural Centre, University of Malaya \\ 50603 Kuala Lumpur \\ e-mail: kwanyie@um.edu.my; drchiu@um.edu.my
}

Published online: 29 June 2017

\begin{abstract}
The purpose of this study is to identify the issues and challenges that music teachers face in teaching multicultural music in primary school classrooms in Malaysia. Using a qualitative methodology, in-depth semi-structured interviews were conducted with 30 music teachers from 12 primary schools. The data was analysed using a "themes-based" analysis of narrative. The findings indicate that these music teachers did not have adequate multicultural training during their college courses. The findings also demonstrate that the music teachers believe that multicultural music education is an essential part of music education. However, the implementation can prove to be difficult due to the fact that many music teachers do not possess appropriate multicultural music knowledge and resources in order to teach multicultural music. Music teachers also reported that the activities and approaches used in the classroom must involve the students actively, rather than passively receptive with a need to allow students to obtain first-hand experience playing traditional musical instruments. In particular, the data provides insights into a number of issues and challenges that music teachers face in implementing multicultural practices in Malaysian primary school music programmes. Hence, music teacher training programmes must take into account the diversity of Malaysian society in order to prepare music teachers to be receptive, tolerant and sensitive to the inclusion of multicultural music in their teaching.
\end{abstract}

Keywords: multicultural music, music education, music teachers, primary schools

\section{Introduction}

As a multiethnic and multicultural nation, Malaysia has shown its uniqueness and treasures among the countries in Southeast Asia. The three main ethnic groups in Malaysia-Malay, Chinese, and Indian-have been sharing languages, lifestyles and cultures with one another. Therefore, providing better harmony and understanding towards various cultures in educational curriculums has become one 
of the most essential missions for Malaysian teachers (Wong \& Chiu, 2016). In this paper, the researchers were concerned with the issues, dilemmas and challenges that music teachers face while teaching multicultural music in the classroom. It is our position that music teachers should not hesitate to explore other musics and cultures. Music teachers should expand musical horizons, demonstrate the value and significance of music from other cultures and educate students about other cultures. In a country with cultural diversity, it is believed that the inclusion of music from other cultures in the school music curriculum can strengthen Malaysian national unity and further build national pride and tolerance.

\section{Context}

\section{Historical Background of Modern Malaysia}

Malaysia is a nation in Southeast Asia divided into East Malaysia (part of Borneo Island) and Peninsular Malaysia (West Malaysia). The historical background of modern Malaysia contains two important incidents: colonisation and migration. Colonisation began with the Portuguese and the Dutch. The two countries ruled present-day Malaysia during the $17^{\text {th }}$ and the $18^{\text {th }}$ centuries respectively while the British took over gradually. In 1826, the British began the settlement of Melaka and extended its colony to include the island of Penang and present-day Singapore. Later on, the Japanese occupied what is present-day Malaysia in 1942. Years later in 1957, after the establishment of the Federation of Malaya, Malaysia announced its independence from Britain with the new country's first Prime Minister Tunku Abdul Rahman (Kennedy, 1962).

During colonisation, the British-Malaysia period, people originating from China, India and Sri Lanka began to immigrate to Malaysia. Today, Malaysia's population is approximately 28.3 million, with an ethnic composition of $50.1 \%$ Malay, $22.6 \%$ Chinese, $11.8 \%$ indigenous, $6.7 \%$ Indian and $0.7 \%$ others (minorities) (Central Intelligence Agency, 2016). The term bumiputera mainly refers to the majority Malay ethnic group and the indigenous people of Peninsular Malaysia, as well as native people in the state of Sarawak and Sabah such as the Kadazan-Dusun, Bajau, Iban and others (Minority Rights Group International, 2016). The uniqueness of multiple cultures in Malaysia has shaped a national education policy that promotes loyalty in order to create values and aspirations to shape national unity and identity.

\section{The History of Music Education in Malaysia}

As early as the 1800s, music courses were introduced at the Penang Free School later followed by English schools in Kuala Lumpur and in the states of Melaka and Ipoh. However, a music curriculum was not established (Mohd Hassan Abdullah, 2007). The reason for this is that the early purpose of education was to help local Malaysians attain better positions in either the public or private industries. Therefore, arts education was not emphasised in the schools. 
On the other hand, the influence of British colonisation in Malaysia has instilled the idea that English culture, in terms of education, law, politics and so forth, is the best. Colonisation gave rise to the idea that only Western/British music education should be considered the standard and most acceptable (Johami Abdullah, 1990). Johami Abdullah's (1993) study found that the definition of music in the Asian sense is distinct especially in Malaysia as a multi-religious nation. Abdullah further states that, "music has never been a part of an Asian tradition. It has always been Western in concept and practice. Furthermore, music education was seldom considered a specialised sub-discipline of music study" (p. 2).

Music activities such as choir and brass band prevailed in the classroom. Added to this, English language classes focused on learning English folksongs and choral singing, and reciting English poems (Yong, 2003). The British-oriented preference in music education gradually changed as the American approach became another option for music educators to receive overseas training (Ramona Mohd Tahir, 2004).

Although Malaysia has had a long and prolific tradition of education, formal music education only began to develop in the 1980s. Initially, the educational emphasis on local and traditional music did not gain much attention. Only the concept of Western or Eurocentric classical music was valued (Johami Abdullah, 1990). Based on his own experience, Shankman (2005) suggests that students should experience their own heritages through the educational school system. Today, the Malaysian music education curriculum has made many changes. In accordance with the latest version of the curriculum, world music was introduced through the Kurikulum Standard Sekolah Rendah (KSSR) in Malaysian primary schools.

\section{Primary Music Education in Malaysia}

Music education is a compulsory subject in the primary schools in Malaysia and is emphasised from ages seven to twelve. The music education curriculum known as the 'Integrated Primary School Curriculum' (Kurikulum Bersepadu Sekolah Rendah, KBSR, 1983) was initially under the management of the Malaysian Ministry of Education in 1983 and was then implemented in all primary schools in 1988. The content of the curriculum followed the ideas of the British education system. Students learnt singing and the playing of instruments such as the recorder and percussion instruments. Some schools provided marching band or choir ensemble as part of the curriculum (Mohd Hassan Abdullah, 2007).

In 2010, in order to make improvements to the existing KBSR and to prepare students to gain more applicable knowledge in music education, the new curriculum system 'Standard Curriculum for World Music for Primary School' (Kurikulum Standard Sekolah Rendah, KSSR) was introduced (KSSR, 2010). The current content of the music curriculum in Malaysian primary schools contains four aspects: aesthetic appreciation, aesthetic perception, creative expression and musical experience (Mubin Md Nor, 2011). These aspects are based on three curricular modules: the Musical Experience Module, the Music Production Module and Music Appreciation Module. In general, students begin at the age of seven and spend six 
years finishing their music study (Official Website of Ministry of Education Malaysia, 2016).

According to the official website of the Ministry of Education Malaysia (2016), the primary music education programme in Malaysia contains two levels; Level One that comprises Year 1-3, followed by Level Two that comprises Year 4-6. Music education is one of the compulsory subjects for both levels. For Level One students, singing is the main focus; for Level Two students, simple music notation is taught for the purpose of learning to play instruments.

\section{The Importance of Multicultural Music Education in Malaysian Context}

According to Banks (1993), multicultural education is a movement designed for different ethnic groups, genders and class levels of students. It enables students who come from an ethnically polarised nation to be more caring and knowledgeable. Malaysia is a multiethnic nation with a colonial history. Ethnic group relations are complex and need to be carefully dealt with especially since it involves different cultures, religions and languages (Shamsul Amri Baharuddin, 2008). Hence, to satisfy the social needs of Malaysia, especially in terms of cultural-ideological factors, the function of the educational system cannot be ignored (Saedah Siraj, Abu Bakar Nordin, \& Norlidah Alias, 2013).

Music education plays a part in developing an individual's self-esteem and patriotism through student awareness of and participation in different musical cultures and genres in Malaysia (Ministry of Education, 2000). Volk (1998) suggests that a multicultural music education will enable students to function musically within the multiple music cultures of a society. Furthermore, children who are raised in a multiethnic region will be familiar with different cultures through multicultural music (Isenberg \& Jalongo, 2010). Malaysia is a society with a diverse population and the researchers are aware that the country's cultural diversity has contributed to increasing demand for a multicultural approach in education specifically in music education.

In 1983, the Integrated Curriculum for Primary School (KBSR) clearly outlined that primary students are entitled to engage with a multicultural music element where students need to appreciate various types of Malaysian musics and cultures. In 2010, the new music curriculum 'Standard Curriculum for World Music for Primary School' developed a multicultural music element where students appreciate a variety of music through their exposure to music from various cultures. Chong (2012) states that music educators should look for ways to include various genres of ethnic music such as Asian music, African music and South American music. The purpose for this is to distance the students from the hegemony of Western classical music that has been mainly taught in schools.

In the Malaysian context, multicultural music education is important in order to help students understand cultural diversity in their own country and encourage inter-ethnic understanding and intercultural communication (Tan, 2008). Chan (2012) further states that music of every culture embodies people's interaction from different cultural backgrounds, worldviews and philosophies. In addition, multicultural music education helps students to be aware of multicultural diversity 
and promotes better understanding, tolerance and acceptance of other kinds of people around them (Wong, Pan \& Shahanum, 2016). Multicultural music education also develops interest and appreciation in the music and songs of Malaysian culture among students (Shah, 2006). Simultaneously, music can be an effective platform to open the doors to multiculturalism and move beyond a hierarchical and eurocentric perception of music (Bradley, 2006).

Since the standards that KBSR require are inclusive of aesthetic appreciation of various types of Malaysian music and cultures, it is significant to ensure that Malaysian primary music teachers have a good approach to multicultural music education in order to teach students. Therefore, the researchers investigated Malaysian primary music teachers' perceptions of multicultural music education that is provided by the teacher-training programme. By understanding the music teachers' learning process during their training sessions, improvement of the training programme's content could be made in order to fulfill the teachers' needs. On the other hand, the researchers also investigated the challenges that music teachers faced while teaching multicultural music in class. For instance, equipment in the classroom such as musical instruments and the students' backgrounds may affect the quality of teaching multicultural music. Moreover, the music teachers' views of the suitability of the teaching approaches and activities adopted for multicultural music were a priority to investigate as well.

In sum, the aim of this research was to identify the issues and challenges that Malaysian music teachers faced while teaching multicultural music at the primary school level. Given the cultural richness that is reflected in classrooms, the study of multicultural music education in Malaysia is receiving more attention from academicians and has long been an issue amongst schoolteachers at the primary and secondary levels. There is substantial research on the multicultural education that is more oriented towards culturally responsiveness, pedagogical approaches and theoretical analyses. However, the research on multicultural music education in particular is still lacking, paving the way for a need to conduct more comprehensive studies in this field. Hence, in order to understand the needs of teachers in the classroom, the researchers feel that a study that identifies music teachers' issues and challenges in teaching multicultural music is appropriate. It is hoped that this study would benefit curriculum developers in deciding upon creating a balanced direction for music teachers' education programmes in Malaysia with regard to multicultural music education.

\section{Methodology}

For the purpose of accumulating data, the researchers used semi-structured interviews in order to allow for in-depth conversations about the participants' views. According to Smith (2005), semi-structured conversation is the most effective way of gaining understanding and perceptions of participants in a study.

Interview participants were selected without regard to research interests or focus of their institutions. For this study, thirty music teachers were selected from 
12 primary schools in Malaysia based on their commitment to teaching and learning of multicultural music. Other recruitment criteria of teachers in this study were based on the interest of their personal and professional experiences and their abilities to express and reflect on the issues and challenges of teaching multicultural music. The participants in this study consisted of 21 females and 9 males. Overall, the participants reported an average of five years of full-time teaching experience in primary schools of Malaysia and all participants interviewed were Malaysian.

Each participant completed a semi-structured interview that consisted of fifteen questions. The interview duration ranged from 20 to 30 minutes and the study was conducted over a six-month period. Twenty face-to-face interviews were conducted at the participants' workplaces. Nine interviews were conducted by phone and one interview questionnaire was completed independently by a research participant and emailed to the researchers. Participation in the study was voluntary, granting the interviewees' anonymity in order to maintain confidentiality.

\section{Analysis of Data}

Data collected from the interviews was qualitatively analysed using an approach of thematic analysis known as Interpretative Phenomenological Analysis (IPA). Generally, the purpose of IPA is for researchers to explore the meanings of the experiences expressed by participants (Pietkiewicz \& Smith, 2014). In order to ensure that this study would yield dependable and credible outcomes, the participants' interview responses were audio recorded with the consent of the participants and transcribed by the researchers. All data was coded, categorised and analysed to illustrate the two significant themes in this study concerning the issues and challenges of teaching multicultural music encountered by Malaysian primary music teachers. The second researcher established the validity of analysis by reviewing the themes for accuracy and authenticity of the data.

\section{Results}

The data was explored and reported in accordance to the following themes:

\section{Theme One: Issues of Teaching Multicultural Music for Malaysian Primary Music Teachers}

Most of the participants expressed that multicultural music education should not be an event that emerges at one particular point in the teacher-training programmes. Instead, it should be included from the start to the finish. Participants reported that they lack knowledge of and responsiveness to the ways that music is situated in culture. This idea also extends to the way in which music teachers present multicultural music education in music classes. Gay (2003) claimed that "teachers must be multicultural themselves before they can effectively and authentically teach students to be multicultural" (p. 4). Butler, Lind and McKoy (2007) express that a problem arises when students have little understanding of the context, function and 
purpose of the musical examples if the teacher's approaches to multicultural music education lack depth and integrity.

Some teachers had the awareness that learning multicultural music is not their only duty. Teacher J2 stated that teachers must, "Also learn to deliver the music or instruct the music in a way that is accurate to the culture". Some teachers believe that they are responsible for learning multicultural music in various aspects.

I think that we should be exposed more to repertoires, methodologies, ways of teaching and learning in multicultural music during our study in the teachers college. I believe it will equip us to serve in a variety of music communities. (Teacher L1)

Meanwhile, participants expressed various views such as the importance of preparing teachers in the teacher education courses to be culturally responsive in the music classroom by offering a range of music that is related to local languages and cultures. Teacher $\mathrm{K}$ mentioned that she had a better understanding by learning songs related to folk customs and festivals such as 'Suasana Hari Raya', 'Gong-xi Gongxi' and 'Deepavali Manaye Suhani' during her teacher training session. Teacher A further addressed that studying the background of multicultural music helped spark her interest, so she was motivated to deliver her knowledge of the music to students.

Page (1995) pointed out that music teachers should seek to tell the stories behind the music they are teaching and present it as authentically as possible, therefore showing respect to the culture that is being taught. Page also suggested that the music teacher should use resources outside of the textbooks and classroom materials and make sure students compare and contrast the new culture with music they are familiar with. To carry out this policy at a national level, multi-racial music should be featured in training courses and textbooks.

Experiencing diverse music instead of only focusing on Western cultures should be the teachers' concern. Teacher J1 said that, "we were mainly Western taught." Teacher J1 explained that the teacher-training programme only provided courses such as Western music theory and learning to play Western classical instruments. Two teachers shared their views regarding a Western-oriented education.

I wish that in the teacher training programmes, we could have experiences outside of the western musical ensemble experiences. Go outside of the classical choir or western musical ensemble experiences that we had in our music department. I think all of us should be engaged in at least one ensemble that is not western based. (Teacher F1)

We need to understand that music of the Western classical tradition is not essentially considered as the topmost of the pyramid and everything else is considered as secondary. (Teacher L2)

Klocko (1989) suggested that the many institutions that adopt a eurocentric worldview, need to be substituted with a more global worldview for higher learning. It includes music outside of the Western art tradition. Schippers (2005) suggested that there is a need to critically reflect on the accomplishment of initiatives aimed at 
providing culturally diverse music education. Moreover, Schippers acknowledges that Western classical music is "the only reference for music education". Participants in this study have noticed that multicultural music was often a neglected area in music education curricula in teacher training colleges and universities.

In addition, participants of the study believe that it is important for multicultural music education to extend beyond music and to also address culture. Some participants stated that it builds an awareness of self-identity and self-esteem by knowing where one comes from and what one can offer by sharing a diversity of music, language and culture that is not confined to local music. Multicultural music education will also help primary school students value a wide spectrum of cultures and celebrate the diversity of music. Teacher $\mathrm{S}$ found that students and including herself became more conscious about their own identities and cultures through multicultural music including sharing world music such as African drums, Native American pow wow music or aboriginal music from Malaysia in music classes. Edwards (1998) encourages music teachers to expose children to diverse music cultures and further suggests that the in-depth study of a limited number of musical cultures is the best path in understanding world music.

Teacher $\mathrm{H}$ realised that children are intelligent and perceptive. The students were highly interested and gave positive responses when the teacher shared multicultural music in class. They gained self-esteem and adored their peers' different identities and cultures. Fitzpatrick (2012) further urges that in order to foster greater respect, clearer understanding and better connections in the music classroom, music educators need to have a culturally relevant pedagogy and acknowledge the rich music heritage each student brings into the class.

Insufficient training in multicultural music education in the teacher training programmes was an issue for some participants. Some teacher educators overlooked the importance of multicultural music education during training sessions. Moreover, some teachers were more comfortable utilising a eurocentric approach that focuses on Western art music. Teacher S reported that the lack of information has made the library or online resources the only way for her to approach multicultural music. Teacher $\mathrm{R}$ had very few opportunities to learn about multicultural music, and she suggested that other teacher educators were not aware of their responsibilities of sharing the diversity of cultures and arts. Teacher $\mathrm{Z}$ hoped that he could have had more chances to practise multicultural music with his peers prior to teaching in the primary school.

Music teachers who had multicultural teaching experiences indicated that there are benefits of integrating multicultural music activities into the music curriculum in order to enhance student interest in learning multicultural music. There are many teaching approaches and activities that encourage students to engage in multicultural music learning activities, such as using traditional musical instruments, accompanying traditional or folk songs with games and activities, music-making and so on. Teacher Y said his students viewed folk songs integrated with dances as particularly exciting especially when the songs had lively melodies and rhythms. Shehan (1986) recommended that the use of simple folk songs to highlight a repetition of melodic and rhythmic patterns is a very good approach to introducing young children to foreign musical cultures. 
All participants of the study remarked that singing and listening activities are natural ways for students to approach multicultural music. Teacher L noticed that rhythm is the key to teaching multicultural music. Students were eager to learn while listening to pieces that have characteristic rhythms. Some teacher participants also came to recognise the students' motivations in learning multicultural music and redesigned their teaching in response. "By obtaining first-hand experience of playing the traditional musical instruments, students had better understanding than studying it from a book," said Teacher S.

Music teachers have also brought up the idea of having a multicultural music showcase presented by the students. By letting students prepare for multicultural music performances or presentations, students reveal showmanship and attempt to learn and improve their knowledge in order to present good performances. Teacher $\mathrm{C}$ stated that her students were always expected to perform traditional music. They were happy and confident while performing in front of an audience. Teacher K's students gained knowledge of multicultural music by the process of collecting information for class presentations. In addition, Teacher F2 believed that students could learn about cultural performance through practice if they are given opportunities to play multicultural music in different musical ensembles at school. Campbell (2004) advocated that for music teachers to teach the performance of a musical style in a culturally appropriate manner, music teachers must focus on the specifics of the music that culture bearers believe to be characteristic and crucial to the style of their music.

\section{Theme Two: Challenges of Teaching Multicultural Music for Malaysian Primary Music Teachers}

In general, the participants of the study appeared to recognise the challenges of the multicultural teaching context. The most prominent data code that occurred had to do with not having adequate time in the music education curriculum when attempting to include multicultural music in their instruction. Shalaway (2005) indicated that $27 \%$ of the school day is taken as being non-instructional in a primary school. Therefore, time management has become one major challenge for teachers. Some participants mentioned that they did not have enough time to teach multicultural music in class. However, the teachers did not have the same problem while teaching other musical elements. They could only briefly introduce multicultural music. Teacher $\mathrm{P}$ reiterated this by stating: "It is always hard to add multicultural music elements in class because there is so much to cover in the music textbook".

Moreover, management of the learning environment is also a challenge for the music teachers, especially when they were in need of traditional musical instruments and therefore keeping the students' interest in learning multicultural music. Teacher $\mathrm{J} 2$ brought up the problem of the shortage of musical instruments. Students easily lose concentration when they do not have hands-on experience in playing the instruments. Quesada (2002) suggested that music teachers should play the music recordings of traditional instruments so that students can hear the specific timbre of the instruments when it is not possible to obtain traditional instruments. 
On the other hand, some participants in the study pointed out that whether students are interested in unfamiliar multicultural music activities or repertoires depend on the students' backgrounds. Some of Teacher E's students are highly interested in approaching multicultural music. She has found one thing in common among these students, "The residents around their neighbourhood are multiracial". Teacher A also recalled that one of her students was not passionate about learning multicultural music because, "My parents told me to only celebrate festivals from our origin". Coleman's documentary has shown that neighbourhood quality or family background might affect a student's knowledge attainment (Egalite, 2016).

Related to the teachers' preparation to teach multicultural music, some participants addressed that preparing multicultural music teaching materials is challenging. Teacher B had a difficult time when preparing for multicultural music teaching material because she did not make much effort to learn multicultural music during her teacher training session. As for Teacher J3, she was not comfortable preparing multicultural music material due to the lack of knowledge and interest. Teacher Y agreed that teachers need to deliver as much multicultural music content knowledge as possible to students; however, she indicated that the stresses and limited time on the subject have made it difficult for teachers to step out of their comfort zones and learn new things. O'Neill (2009) indicates that many music teachers avoid making music choices that make them uncomfortable, inadequate and less effective for teaching, including music from other cultures that they have no experience or musical expertise to draw on. It is believed that without fully learning and understanding of multiple cultures, music teachers are not capable of attracting student attention.

\section{Conclusion}

The findings from this research have implications for multicultural music education teaching in Malaysia. The difficulties experienced by music teachers for teaching multicultural music need to be addressed. Awareness of the issues revolving around assisting and enhancing the multicultural elements in teacher training programmes needs to be raised. In this study, music teachers felt that multicultural music education is essential to music teacher preparation programmes and should be incorporated into all aspects of music education curriculum through the use of culturally responsive teaching and culturally diverse curricular resources and activities. The findings of this study also indicated that most of the music teachers reported favourable attitudes toward the use of multicultural music in the classroom. However, the teachers reported inadequate preparation in the area of multicultural music pedagogy. Music teachers further expressed that they need more opportunities for continuing professional multicultural music training in order to empower them to integrate multicultural music education into their music classes. The results of this study also reveal that most of the music teachers found that singing, listening and practical hands-on music activities are the most effective approaches for all concerned. Music teachers expressed that these approaches are more successful than 
reading to children in a direct way about being more multi-cultural. Therefore, it is the responsibility of music teacher educators to instil and provide rich multicultural music programmes within the music teacher education courses and primary schools in Malaysia. It is believed that in Malaysia, multicultural music education enables students to understand the uniqueness of cultures that furthers the appreciation of universal qualities that bind the cultures together (Wong, Pan \& Shahanum, 2016).

Hence, in order to provide a more complete assessment of the status of multicultural music education in the music teacher-training programmes in Malaysia, more research into multicultural music education curricular requirements of all music teacher-training programmes is needed. The research in the development of multicultural music education for primary school is significant and also meets the current requirements. Therefore, by improving and refining the music education curriculum, a culturally responsive teaching approach provides opportunities for students to be exposed to diverse cultures. Given the multicultural characteristics of Malaysia it is important that music teachers and students immerse themselves in multicultural music education to ensure that music education remains relevant in Malaysia's diverse society.

\section{References}

Banks, J.A. (1993). Multicultural education: Development, dimensions, and challenges. The Phi Delta Kappan, 75(1), 22-28.

Bradley, D. (2006). Music education, multiculturalism, and anti-racism - Can we talk? Action, Criticism \& Theory for Music Education, 5(2). Retrieved July 24, 2008, from http://act.maydaygroup.org/articles/Bradley5_2.pdf

Butler, A., Lind. V., \& McKoy, C. (2007). Equity and access in music education; Conceptualizing culture as barriers to and supports for music learning. Music Education Research, 9 (2) 241-253.

Campbell, P. S. (2004). Teaching music globally: Experiencing music, expressing culture. New York, NY: Oxford University Press.

Central Intelligence Agency (2016). Retrieved from https://www.cia.gov/library/publications/the-world-factbook/fields/2075.html

Chan, C.S.C. (2012). P. Ramlee's music: An expression of local identity in Malaya during the mid-twentieth century. Malaysian Music Journal, 1(1), 16-32.

Chong, P. L. (2012). East Malaysian music in the classroom: Kenyah and Kadazandusun recreational songs and Jatung Utang (Kenyah xylophone). Malaysian Music Journal, 1(2), 20-43.

Department of Statistics Malaysia, Official Portal. Last modified 2016. Retrieved from https://www.statistics.gov.my/index.php?r=column/ctheme\&menu_id=L0pheU43N WJwRWVSZklWdzQ4TlhUUT09\&bul_id=MDMxdHZjWTk1SjFzTzNkRXYzcV Zjdz09.

Edwards, K. (1998). Multicultural music instruction in the elementary school: What can be achieved? In Bulletin of the Council for Research in Music Education, 138, 62- 82.

Egalite, Anna J. (2016). How family background influences student achievement. Education Next, 16(2). Retrieved from http://educationnext.org/how-family-backgroundinfluences-student-achievement/ 
Fitzpatrick, K. R. (2012). Cultural diversity and the formation of identity: Our role as music teachers. Music Educators Journal, 98(4), 53-59.

Isenberg, J.P. \& Jalongo, M.R. (2010). Creative thinking and arts based learning: Preschool through fourth grade ( $5^{\text {th }}$ ed.). Upper Saddle River, NJ: Pearson Education, Inc.

Gay, G. (2003). The importance of multicultural education. Educational Leadership, 61(4), 30-35.

Johami Abdullah (1990). Music education in Malaysia: An overview. The Quarterly Journal, 1(4), 44-53.

Kementerian Pendidikan Malaysia. (1983). Buku panduan muzik KBSR untuk Tahap I dan tahap II. Kuala Lumpur: Dewan Bahasa dan Pustaka.

Kementerian Pelajaran Malaysia (2010). Kurikulum Standard Sekolah Rendah (KSSR): Tahun Satu. Putrajaya: Bahagian Pembangunan Kurikulum.

Kementerian Pelajaran Malaysia (2011). Kurikulum Standard Sekolah Rendah (KSSR): Tahun Dua. Putrajaya: Bahagian Pembangunan Kurikulum.

Kennedy, Joseph (1962). A history of Malaya, A.D. 1400-1959. New York: St. Martin's Press.

Klocko, D. G. (1989). Multicultural music in the college curriculum. Music Educators Journal, 75(5), 38-41.

Minority Rights Group International (2016). Retrieved from http://minorityrights.org/

Mohd Hassan Abdullah (2007). Music education in Malaysian public school: Implementation, issues and challenges. Journal Pendidikan Bitara UPSI, 1, 33-48.

Mubin Md Nor (2011). Develop human capital through music education in Malaysia. Academic Research International, 1(2), 220-227.

O'Neill, S. (2009). Revisioning musical understandings through a cultural diversity theory of difference. In E. Gould, J. Countryman, C. Morton \& L.Stewart Rose (Eds.), 70-89. Exploring Social Justice (Vol. IV). Toronto: Canadian Music Educator's Associaton.

Page, N. (1995). Sing and shine on!: The teacher's guide to multicultural song leading. Portsmouth, NH: Heinemann Publishing.

Pietkiewicz, I., \& Smith, J. A. (2014). A practical guide to using interpretative phenomenological analysis in qualitative research psychology. Psychological Journal, 20, 7-14.

"Primary education." Official Website of Ministry of Education Malaysia. Retrieved from http://www.moe.gov.my/en/pelajaran-rendah

Quesada, M. A. (2002). Teaching unfamiliar styles of music. In B. Reimer, (Ed.) World Musics and Music Education, 139-159. Reston, VA: National Association for Music Education.

Ramona Mohd Tahir (2004). Proceedings from The $18^{\text {th }}$ International Scientific and Practical Conference 2004: Music and music education in Malaysia: A state of affairs. Music Pedagogical Education between the $20^{\text {th }}$ and $21^{\text {st }}$ centuries. Moscow Khanty-Mansysck: Moscow State Pedagogical University, Russia, 2004.

Saedah Siraj, Abu Bakar Nordin, \& Norlidah Alias (2013). National integration in multicultural school setting in Malaysia. The Malaysian Online Journal of Educational Science, 1(1), 20-29.

Schippers, H. (2005). Taking distance and getting up close: The seven-continuum transmission model (SCTM). In P. S. Campbell, J. Drummond, P. Dunbar-Hall, K. Howard, H. Schippers, T. Wiggins. (Eds), 29-34. Cultural diversity in music education: directions and challenges for the 21st century. Brisbane, Australia: Australian Academic Press. 
Shahanum Mohamad Shah (2006). Popular music in Malaysia: Education from the outside. International Journal of Music Education, 24(2), 135-142.

Shalaway, Linda (2005). Learning to teach... not just for beginners: The essential guide for all teachers. New York, NY: Scholastic Inc.

Shamsul Amri Baharuddin (2008). Modul hubungan etnik. Selangor, Malaysia: Pusat Penerbitan Universiti, Universiti Teknologi MARA

Shankman, I. (2005). The importance of world music in music education. Retrieved October 21, 2016 from http://www.artistshousemusic.org/

Shehan, P. K. (1986). Towards tolerance and taste: Preferences for world musics. British Journal of Music Education, 3(2), 153-163.

Smith, J. A. (2005). Semi structured interviewing \& qualitative analysis. In J.A. Smith, Rom Harré, and Luk Van Langenhove (Eds), Rethinking methods in psychology, (9-26). London: Sage Publication.

Tan, S.B. (2008). A Paradigm Shift in Teaching Music in Schools: Traditional Music and Multiculturalism in Malaysian Education: Approaches in Music Appreciation Classes. In Education for the arts. In L. Joubert (Ed), Education for the arts: The Asian experience: Twenty-Four Essays, 249-260. Dordrecht, The Netherlands: Springer.

Volk, T. M. (1998). Music, education, and multiculturalism: Foundations and principles. New York, NY: Oxford University Press.

Wong, K.Y. \& Chiu, M.Y. (2016). Music teachers' perceptions of teaching multicultural music in Malaysia. Paper presented at the 1st International and Interdisciplinary Conference on Arts Creation and Studies (IICACS) 2016 (24-25 August 2016). Surakarta: Institut Seni Indonesia.

Wong, K. Y., Pan, K. C. \& Shahanum Mohamad Shah (2016). General music teachers' attitudes and practices regarding multicultural music education in Malaysia. Music Education Research, 18(2), 208-223.

Yong, L. J. B. (2003). The roles of the Malaysian government and private sectors in the development of music education (unpublished master dissertation). University of Florida, Florida USA.

\section{Biography}

Wong Kwan Yie received her Ph.D. in Music Education from the University of Malaya. Her $\mathrm{PhD}$ study was sponsored by the Skim Latihan Akademik IPTA (SLAI) offered by the Ministry of Higher Education of Malaysia. Her research interests include multicultural music education, choral music education and Malaysian music. Wong is now a senior lecturer in University of Malaya, Malaysia.

Chiu Ming Ying is from Taiwan. She received her Bachelor of Arts degree and Master of Arts degree in Taiwan, and received the Doctor of Musical Arts degree from Louisiana State University, the United States. Chiu is currently serving as senior lecturer in University of Malaya, Malaysia. 